\title{
Systemic eosinophilia with skin and pulmonary infiltrates in a patient with chronic lymphocytic leukemia: A case report
}

\author{
Veronika Nagy ${ }^{* 1}$, Corina Dommann-Scherrer ${ }^{2}$, Alexandar Tzankov ${ }^{3}$, Miklos Pless $^{1}$ \\ ${ }^{1}$ Department of Medical Oncology, Kantonsspital Winterthur, Winterthur, Switzerland \\ ${ }^{2}$ Institute of Pathology, Kantonsspital Winterthur, Winterthur, Switzerland \\ ${ }^{3}$ Institute of Pathology, University Hospital Basel, Basel, Switzerland
}

Received: January 8, 2016

DOI: $10.5430 /$ crcp.v3n2p15

\author{
Accepted: February 6, 2016 \\ Online Published: February 24, 2016
}

URL: http://dx.doi.org/10.5430/crcp.v3n2p15

\begin{abstract}
We report on a patient with chronic lymphocytic leukemia (CLL) under treatment with fludarabine who developed skin ulcers, systemic eosinophilia and pulmonary infiltrates. Despite extensive diagnostic investigations, no cause of the clinical findings could be detected. After unsuccessful treatment with prednisone and hydroxyurea, the patient died. Autopsy revealed a surprising diagnosis, explaining all symptoms and findings.
\end{abstract}

Key Words: Chronic lymphocytic leukemia, Eosinophilia, Eosinophilic granuloma, Richter, Hodgkin lymphoma, Skin ulcer, Lung infiltrate

\section{INTRODUCTION}

Chronic lymphocytic leukemia (CLL) is the most common leukemia in adults in the Western world and is frequently accompanied by eosinophilia. The differential diagnosis of eosinophilia is very wide, including infection, allergic diseases, myeloproliferative disorders, ${ }^{[1]}$ lymphoid malignancies, ${ }^{[2,3]}$ side effects of medical treatment of CLL with fludarabine, ${ }^{[4]}$ and other causes. ${ }^{[5]}$ We present and discuss the case of a patient who developed dramatic clinical features: rapid deterioration of performance status, high fever, extremely high eosinophilic counts in peripheral blood, as well as eosinophilic infiltrates in skin and lungs.

\section{Case presentation}

In 2006, a 75-year-old man who received fludarabine for B-CLL presented with several small, crusted excoriations on his forehead. In addition, he demonstrated a 4-centimeter axillary ulcer (see Figure 1) which he had first noticed two weeks after the most recent fludarabine infusion. Except for a minor generalized pruritus, he reported no further symptoms.

Ten years ago, the patient initially presented with supraclavicular, axillary and inguinal lymphadenopathy. Biopsy of a supraclavicular lymph node revealed small lymphocytic lymphoma SLL/CLL, CD20, CD5, CD23 positive with lambda light chain restriction, RAI stage I. In the subsequent years, symptomatic lymphadenopathy with involvement of the submandibular gland and left tonsil, lymphocytosis and thrombocytopenia developed. Over the years, six cycles of chlorambucil and prednisone and four cycles of cyclophosphamide, adriamycine, vincristine, etoposide and prednisone (CHOEP) respectively, were administered, each leading to

\footnotetext{
*Correspondence: Veronika Nagy; Email: veronika.nagy@ksw.ch; Address: Department of Medical Oncology, Kantonsspital Winterthur, Brauerstrasse 158401 Winterthur, Winterthur, Switzerland.
} 
partial remission and a treatment-free interval of two to three years. There was no evidence of transformation. Eventually, progressive lymphadenopathy, splenomegaly, lymphocytosis $\left(43.4 \times 10^{9} / \mathrm{L}\right)$, anemia (hemoglobin $\left.11.9 \mathrm{~g} / \mathrm{dl}\right)$ and thrombocytopenia $\left(114 \times 10^{9} / \mathrm{L}\right)$ occurred. B-symptoms were not present. Three cycles of single agent fludarabine $(25 \mathrm{mg}$ per square meter on days one to three of a four-week cycle, corresponding to a dose reduction to $60 \%$ of standard dose due to limited bone marrow reserve in this elderly, pretreated patient) resulted in partial response of lymphadenopathy, and lymphocyte count regressed to $4.7 \times 10^{9} / \mathrm{L}$. At this time, skin ulcers on forehead and axilla and eosinophilia $\left(1.1 \times 10^{9} / \mathrm{L}\right)$ appeared. A swab and microbiologic cultures of the axillary ulcer did not reveal an infectious cause. PCR analysis and cultures for Mycobacterium tuberculosis remained negative. An excisional biopsy of the ulcerated axillary lesion showed a CD1a and S-100 protein positive histiocytic infiltrate with focally massively interspersed eosinophils, some lymphocytes and small areas of necrosis in dermis and subcutaneous tissue. The favored diagnosis was eosinophilic granuloma (see Figure 2) without evidence of CLL.

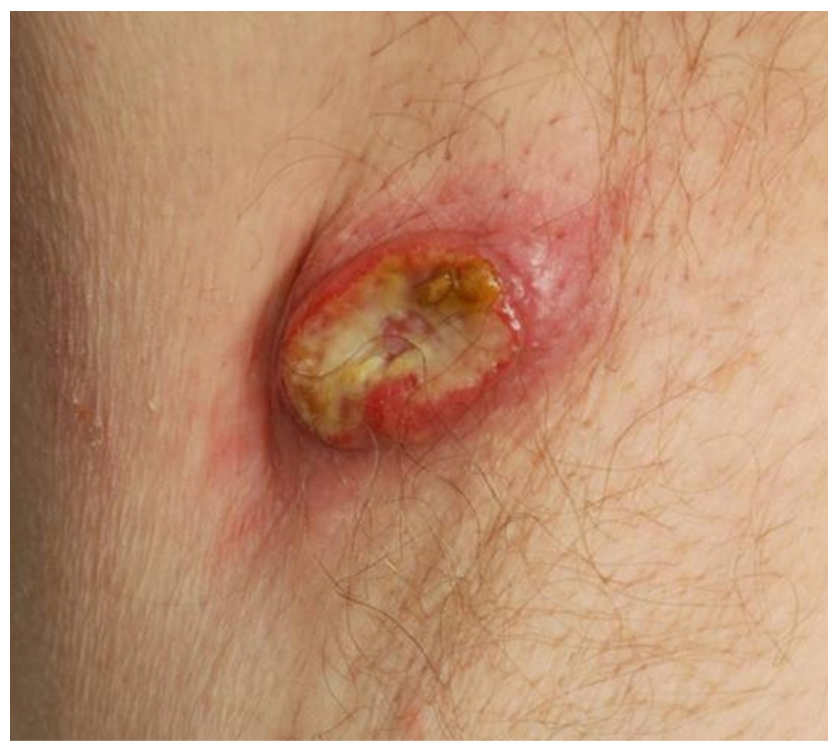

Figure 1. Axillary skin ulcer

One week later, the patient was admitted to the hospital with fever, chills, and fatigue. Peripheral blood count showed leukocytosis $\left(46.5 \times 10^{9} / \mathrm{L}\right)$, lymphocytosis $\left(14.0 \times 10^{9} / \mathrm{L}\right)$, eosinophilia $\left(22.6 \times 10^{9} / \mathrm{L}\right)$, and anemia (hemoglobin $10.2 \mathrm{~g} / \mathrm{dl}$ ). A chest CT scan revealed numerous bilateral pulmonary micronodulary infiltrates (see Figure 3 ).

By fiberoscopic bronchoscopy with bronchoalveolar lavage (BAL) and transbronchial biopsies, eosinophilic alveolitis (76.5\% eosinophilic granulocytes in BAL fluid) was demonstrated. A pulmonary biopsy showed granulomas with eosinophilic infiltrates without any specificity, particularly without admixture of CD1a or S-100 positive histiocytes. Pneumocystis jirovecii or other infectious, viral, bacterial, opportunistic or parasitic agents were not detected. Flow cytometry of peripheral blood revealed a clonal B-cell-population consistent with CLL. Bone marrow biopsy showed, besides CLL, $45 \%$ eosinophils, but no evidence of myelodysplasia or myeloproliferation. Testing for the JAK2 V617F mutation and the FIP1L1-PDGFRalpha fusion gene, distinct genetic alterations which may be present in Philadelphia chromosome (Ph1) negative myeloproliferative neoplasms and subtypes of chronic eosinophilic leukemia respectively, were negative. Despite initiation of treatment with $100 \mathrm{mg}$ prednisone orally per day, leukocytosis $\left(92.3 \times 10^{9} / \mathrm{L}\right)$, lymphocytosis $\left(41.1 \times 10^{9} / \mathrm{L}\right)$ and eosinophilia $\left(35.1 \times 10^{9} / \mathrm{L}\right)$ progressed, and the patient's clinical condition worsened. By administration of hydroxyurea ( $2 \mathrm{~g}$ per day), a temporary reduction of eosinophilia was achieved, but thrombocytopenia $\left(5 \times 10^{9} / \mathrm{L}\right)$ and anemia $(\mathrm{Hb} 7.4 \mathrm{~g} / \mathrm{dl})$ worsened. When hydroxyurea was stopped, eosinophil counts immediately rose again. Thrombocyte and erythrocyte transfusions were given. Bone marrow aspirate revealed increased eosinophils and absence of megakaryocytes, but no CLL. Over the following days, the patient's clinical condition deteriorated and he died, ten years after initial diagnosis of B-CLL and four months after first appearance of skin ulcers.

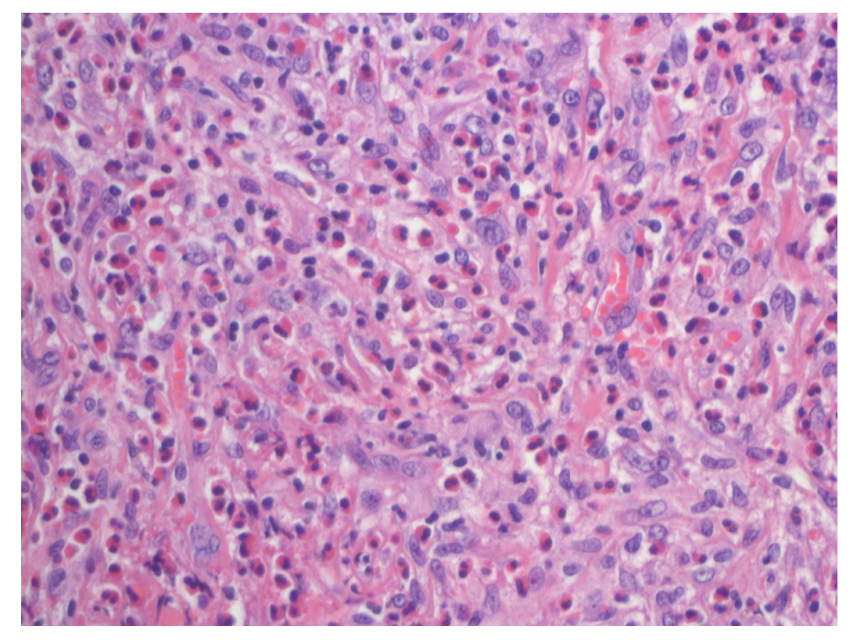

Figure 2. HE-stained tissue section of skin ulcer The dermal mixed cellular infiltrate is mainly composed of histiocytes and eosinophils (HE, original magnification 400×).

An autopsy was performed. The immediate cause of death was an extensive acute myocardial infarction due to coronary arteriosclerotic stenosis and thrombosis probably triggered by a bilateral acute pneumonia with pleural effusions. Unexpectedly, miliar infiltrates of classical Hodgkin lymphoma (HL), lymphocyte-depleted subtype, were present in both 
lungs (see Figure 4), the spleen and in the liver, as well as in abdominal lymph nodes, and bone marrow. No residual infiltrates of CLL were found in lymph nodes, bone marrow and parenchymatous organs.

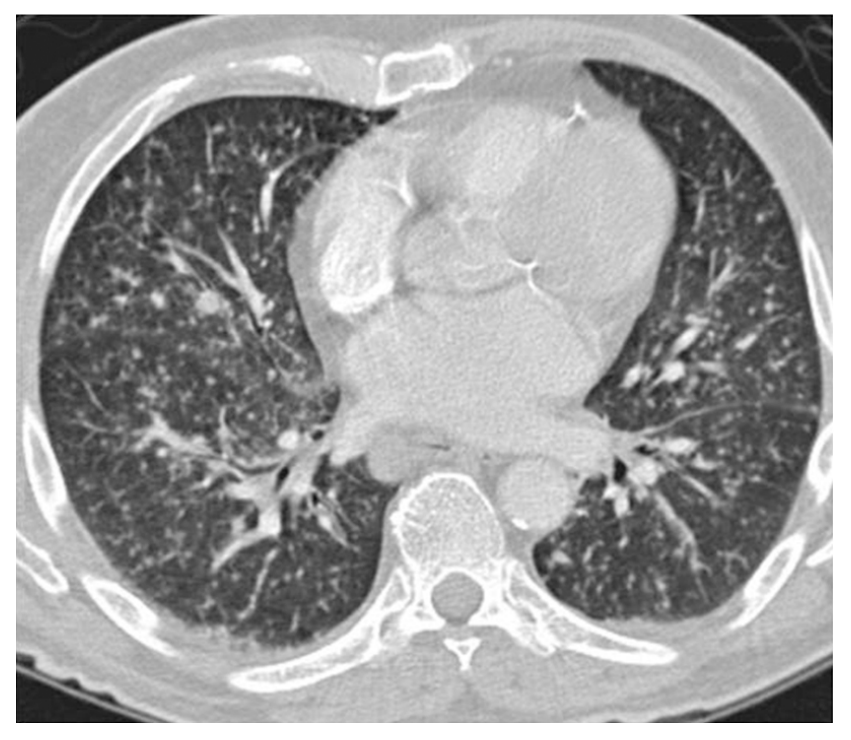

Figure 3. Chest CT scan showing extensive, micronodulary infiltrates in both lungs

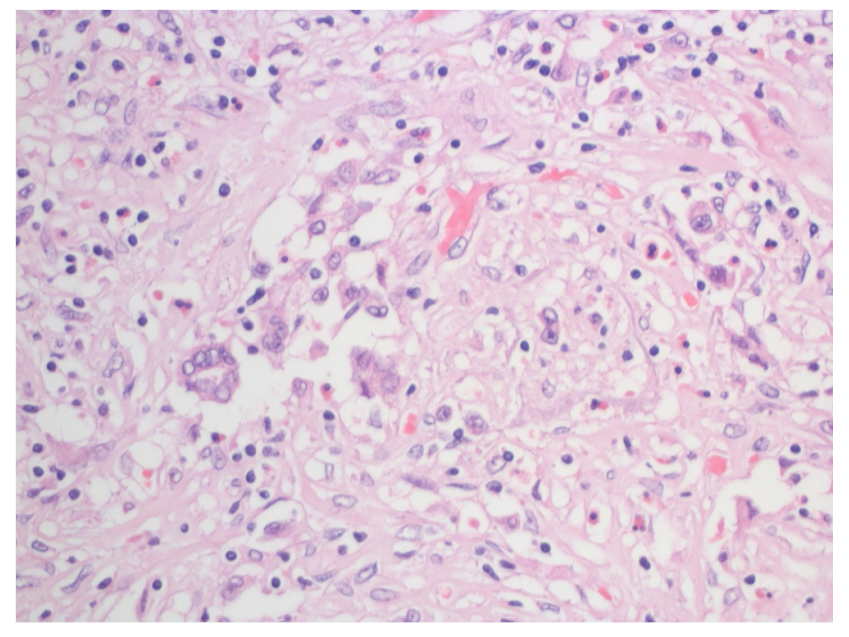

Figure 4. Histology of autopsy lung specimen

Nodular infiltrates of classical Hodgkin Lymphoma, lymphocyte depleted subtype displaying sparse mononuclear and multinuclear HRS cells on the background of histiocytes, some lymphocytes and rare eosinophils (HE, original magnification 400×).

Histopathologic review of the formerly excised ulcerated axillary mass including additional immunohistochemistry identified scattered atypical, mononuclear large cells staining positive for CD30 (see Figure 5) and MUM1 and negative for CD20, PAX5, CD3, CD15, S-100 and CD1a, thus showing the immunophenotype of Hodgkin and Reed-Sternberg (HRS) cells.

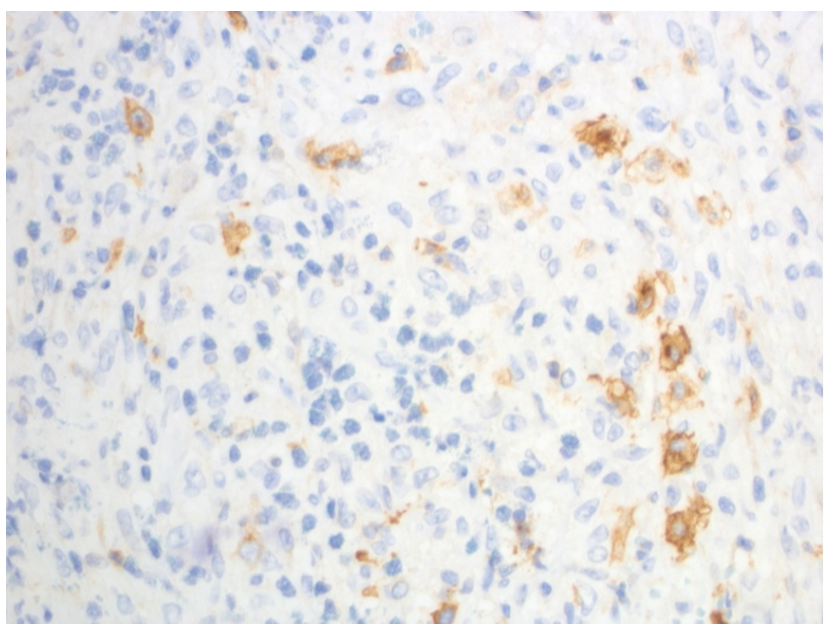

Figure 5. Immunohistochemistry of skin ulcer Retrospective immunostaining for CD30 showing occasional transformed large cells, identified as HRS cells intermingled in a histiocytic and eosinophilic infiltrate (original magnification $400 \times)$

Clonality of CLL cells (tonsil, bone marrow aspirate) was demonstrated using polymerase chain reaction $(\mathrm{PCR})$ and framework analysis of the immunoglobulin heavy chain (IGHV) gene as described elsewhere. ${ }^{[6]}$ Direct genome sequencing of the monoclonal PCR products of CLL cells was compared to corresponding germline sequences and demonstrated absence of IGHV mutation. 500 HRS cells were isolated by laser capture microdissection of the CD30-stained autopsy specimen. Fragment length comparison analysis of the PCR products suggested lack of clonal relationship of the CLL and HRS cells of the classical HL (see Figure 6).

\section{Discussion}

When this patient with CLL presented with fever, skin ulcers and systemic eosinophilia, we were confronted with major challenges in differential diagnostics. Our first assumption was an infection in an immunocompromised patient under fludarabine treatment. However, microbiological analyses did not confirm any bacterial, mycobacterial, fungal or parasitic pathogen. The presence of CD1a and S-100 protein positive, histiocyte- and eosinophil-rich infiltrates in the axillary skin ulcer biopsy led to suspicion of eosinophilic granuloma, a localized form of Langerhans cell histiocytosis ( $\mathrm{LCH})$. LCH is defined as a clonal proliferation of Langerhans cells characterized by CD1a and S-100 expression with uni- or multifocal affection of bones, visceral organs, skin or lymph nodes. Rarely, general symptoms such as fever, malaise and peripheral eosinophilia may be present. ${ }^{[7]}$ Since bilateral, miliary pulmonary infiltrates were also detected in our patient, we considered pulmonary LCH. However, bronchoalveolar lavage showed eosinophilic alveolitis, but no evidence of 
LCH. Lung biopsies demonstrated histologically unspecific histiocytic infiltrates without expression of CD1a or S-100. Thus, we considered other causes for systemic eosinophilia and lung infiltrates. Severe eosinophilia may be associated with hematological malignancies such as chronic myeloproliferative disorders and, usually with less pronounced eosinophilic counts, with CLL, HL, ${ }^{[1]}$ and fludarabine treatment. ${ }^{[4]}$ Clonal eosinophilia was unlikely considering negative tests for the FIPIL1-PDGFRalpha fusion gene and the $J A K 2$ V617F mutation. Eosinophilic pneumonia after fludarabine treatment has been reported previously. ${ }^{[8]}$ High-dose systemic steroid therapy is recommended for fludarabineinduced eosinophilic pneumonitis and can lead to clinical improvement and resolution of lung infiltrates. ${ }^{[9]}$ Therefore, we initiated treatment with prednisone, but no improvement of symptoms or eosinophilic counts was observed. Subsequently, an attempt of treatment with hydroxyurea was unsuccessful as well, and the patient died. Surprisingly, autopsy showed disseminated organ and bone marrow infiltrates of classical HL, lymphocyte-depleted subtype, without evidence of CLL. Although association of newly diagnosed HL with peripheral blood eosinophilia in approximately $15 \%$ is a well-known phenomenon, elevated blood eosinophil counts are uncommon in lymphocyte-depleted subtype and rarely exceed $1 \times 10^{9} / \mathrm{L}$, let alone extreme eosinophilia of over $35 \times 10^{9} / \mathrm{L}$ as in the case presented here. ${ }^{[10,11]}$

In an attempt to clarify the relationship of the cutaneous eosinophilic granuloma-like lesion diagnosed shortly prior to death and the multiorgan manifestations of HL detected at autopsy, a review of the skin biopsy with extensive additional immunohistochemical studies was performed. Retrospectivelly, focally intermingled, CD30 positive large mononuclear cells without prominent nucleoli that did not stain for CD20 or $\mathrm{CD} 3$ were identified, thus being compatible with mononuclear variants of HRS cells in an inflammatory background. In the context of disseminated HL, it was concluded that the lesion corresponded to a cutaneous manifestation of $\mathrm{HL}$ obscured by a predominant proliferation of CD1a and S-100 protein positive Langerhans cells and eosinophils, the latter component being indistinguishable from eosinophilic granuloma (see Figures 2 and 5). In contrast to clonal Langerhans cells in eosinophilic granuloma, the Langerhans cells and eosinophils blurring the HRS cells in the skin biopsy are of reactive nature. Reactively proliferated Langerhans cells are known to occur rarely in HL, ${ }^{[12,13]}$ most likely as a result of cytokine and chemokine production of HRS cells. Furthermore, rare cases of true eosinophilic granuloma associated with HL in lymph nodes have been observed. ${ }^{[14,15]}$ As HL infiltrates may contain numerous eosinophils, these cases represent a diagnostic challenge.
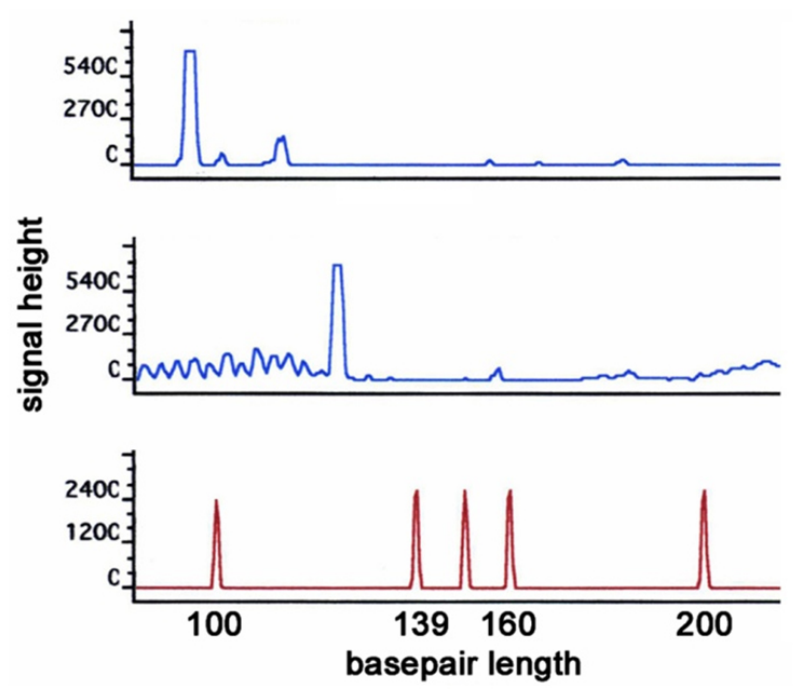

Figure 6. Fragment length comparison analysis Microdissected HRS cells of the HL component show monoclonal rearrangement of 95 base pair (bp) with restriction fragment length polymorphism analysis of the IGHV gene (upper row), being distinct from the monoclonal rearrangement of $127 \mathrm{bp}$ in the SLL/CLL component (middle row). Basepair scale is in the lower row

Persons affected by CLL are at an increased risk for the development of secondary malignancies, ${ }^{[16-19]}$ mostly lymphomas. $2 \%$ to $8 \%$ of patients with B-CLL show progression to a clinical entity known as Richter syndrome/Richter transformation (RS/RT). ${ }^{[20,21]} \mathrm{RS} / \mathrm{RT}$ most commonly represents progression of CLL into diffuse large B-cell lymphoma (DL$\mathrm{BCL}),{ }^{[22,23]}$ and should be suspected when rapid clinical deterioration, fever in absence of infection, and rapidly enlarging lymphadenopathy appear in a patient with CLL. ${ }^{[20]}$ In a cohort study of newly diagnosed patients with CLL between 2000 and 2011 at Mayo Clinic, the incidence of RS/RT was 2.3\%. ${ }^{[24]}$ According to retrospective data, development of CLL into HL (termed Hodgkin variant of Richter transformation, HvRT) occurs in $0.4 \%$ of patients with CLL with a male predominance. ${ }^{[19,25]}$ Two types of HvRT have been postulated: ${ }^{[26]}$ In type 1 transformation, HRS-like cells are interspersed with CLL lymphocytes without the typical inflammatory background of HL. ${ }^{[20,25-28]}$ Clonality studies demonstrate heterogeneous results showing clonal relationship in some of the cases. ${ }^{[6,29]}$ In contrast, type 2 transformation is characterized by the occurrence of classical HL with HRS cells intermingled in the characteristic inflammatory background infiltrate separately from the CLL cells. Molecular analyses provide evidence in many cases for separate clonal origins of both tumors supporting development of $\mathrm{HL}$ as a distinct second malignancy. ${ }^{[20,26,30,31]}$ While different pathogenetic mechanisms are discussed in both types of transformation, only type 2 is considered as true Hodgkin 
transformation irrespective of clonal relationship with the underlying CLL cells. ${ }^{[6,20,29-32]}$ In our patient, morphological and immunohistochemical findings at autopsy showed classical HL, namely type 2 transformation. Approximately half of CLL cases carry a mutation in the variable region of the $I G H V$ gene. ${ }^{[33]}$ In CLL, unmutated IGHV status (as in our patient) is one of several adverse prognostic markers that are independently associated with more aggressive, advanced stage CLL with significantly lower overall survival and higher risk for development of RS/RT. ${ }^{[24,34]}$ In a recent series of classic RS/RT, 78\% of CLL cases showed clonal progression into DLBCL with identical IGHV sequences in both lymphoma components. Among those clonally related RS/RT cases, more than $70 \%$ carried unmutated $I G H V$ genes, whereas most clonally unrelated cases displayed $I G H V$ gene mutations in the CLL component. ${ }^{[6]}$ In contrast, CLL with HvRT (type 1 and type 2) predominantly carry mutated $I G H V$ genes, independent of a clonal relationship. ${ }^{[6,30,35]}$ Thus, our case represents an unusual HvRT developing in the background of $I G H V$-unmutated CLL, which fits to the lack of clonal relationship of both components suggested by the results of fragment length comparison analysis of IGHV PCR products.

Whereas primary HL is associated with EBV infection in $30 \%$ in developed countries, ${ }^{[36-39]}$ the role of EBV in the pathogenesis of HvRT is ambiguous. Negativity for EBV has been described mainly in clonally related cases of CLL and HL. In contrast, in many published cases of clonally unrelated HL and CLL, EBV-infection was present. ${ }^{[6,31,40]}$ Immunosuppression induced by fludarabine treatment has been suggested to play a role in the pathogenesis of EBV positive HvRT, ${ }^{[31]}$ and cases of clonally related CLL and HL associated with EBV after fludarabine therapy have been described. ${ }^{[40]}$ Interestingly, in the case reported here, the HRS cells of HvRT were EBV-negative in the absence of clonal relationship between CLL and HL.

Within the last decade, major advances in treatment of CLL have been accomplished. In the mid to late 2000s, standard first line treatment of CLL changed from single agent chemotherapy to rituximab-based chemoimmunotherapy. ${ }^{[41]}$ As our patient was treated prior to approval of rituximab for CLL in Switzerland, he was unable to benefit from this development. Currently, anti-CD20 mono- clonal antibodies (rituximab, ofatumumab or obinutuzumab) in combination with chemotherapeutic agents are standard of care in treatment of CLL. ${ }^{[41,42]}$ Considering the current approach for elderly patients with CLL, this patient would most likely have received a chemoimmunotherapeutic treatment regimen such as obinutuzumab/chlorambucil ${ }^{[42,43]}$ or rituximab/bendamustine. ${ }^{[44,45]}$ Recently, another paradigm shift in treatment of relapsed or refractory CLL has been heralded by the introduction of promising new treatment concepts including inhibition of Bruton's tyrosine kinase (BTK), phospoinositide 3-kinase (PI3K) delta or B-cell lymphoma 2 (Bcl2) and many other novel agents. ${ }^{[41,42]}$ Given the extended treatment armamentarium available nowadays and in the near future, this elderly patient would probably not be treated with fludarabine today.

HvRT commonly shows an aggressive clinical course and typically leads to death in a majority of patients within one year from diagnosis. ${ }^{[46]}$ When multiagent chemotherapy is administered, overall response rates of around $50 \%$ and short progression-free intervals have been reported. ${ }^{[20,25]}$ Generally, clinical outcomes are worse than in de novo HL. ${ }^{[20,25,32]}$ A retrospective analysis demonstrated that patients previously treated for CLL with fludarabine displayed a more aggressive course of HL and a shorter mean survival of 0.7 years compared to 2.1 years in the non-fludarabine group. ${ }^{[20]}$

\section{Conclusion}

We conclude that unexpected clinical findings, especially eosinophilia, in a patient with CLL, as described in this report, should lead to inclusion of HvRT in differential diagnosis. Repeated invasive diagnostic procedures with biopsy of suspicious lesions are necessary to come to a clear diagnosis in such complex cases, and close collaboration between clinicians and pathologists within the diagnostic process is mandatory.

\section{ACKNOWLEDGeMENTS}

The authors gratefully acknowledge Sergio Cogliatti for performance of molecular analyses and valuable scientific input on molecular genetics and help with the section of the manuscript concerning molecular pathology.

\section{CONFlicts of InTEREST Disclosure}

The authors declare no conflicts of interest.

\section{REFERENCES}

[1] Andersen CL, Siersma VD, Hasselbalch HC, et al. Eosinophilia in routine blood samples and the subsequent risk of hematological malignancies and death. American journal of hematology. 2013; 88(10):
843-7. PMid: 23765950. http://dx.doi.org/10.1002/ajh.2 3515

[2] Borish L, Dishuck J, Cox L, et al. Sezary syndrome with elevated serum IgE and hypereosinophilia: role of dysregulated cytokine pro- 
duction. The Journal of allergy and clinical immunology. 1993; 92(1 Pt 1): 123-31. PMid: 8335848. http://dx.doi.org/10.1016/0 091-6749 (93) 90046-I

[3] Gruss HJ, Brach MA, Drexler HG, et al. Expression of cytokine genes, cytokine receptor genes, and transcription factors in cultured Hodgkin and Reed-Sternberg cells. Cancer research. 1992; 52(12): 3353-60. PMid: 1596893.

[4] Sezer O, Schmid P, Hallek M, et al. Eosinophilia during fludarabine treatment of chronic lymphocytic leukemia. Annals of hematology. 1999; 78(10): 475-7. PMID: 10550560. http://dx.doi.org/10. $1007 / \mathrm{s} 002770050602$

[5] Mejia R, Nutman TB. Evaluation and differential diagnosis of marked, persistent eosinophilia. Seminars in hematology. 2012; 49(2): 149-59. PMid: 22449625 . http://dx.doi.org/10.1053/j.sem inhematol.2012.01.006

[6] Mao Z, Quintanilla-Martinez L, Raffeld M, et al. IgVH mutational status and clonality analysis of Richter's transformation: diffuse large B-cell lymphoma and Hodgkin lymphoma in association with B-cell chronic lymphocytic leukemia (B-CLL) represent 2 different pathways of disease evolution. The American journal of surgical pathology. 2007; 31(10): 1605-14. PMid: 17895764 http://dx.doi.org/10.1097/PAS.0b013e31804bdaf8

[7] Howarth DM, Gilchrist GS, Mullan BP, et al. Langerhans cell histiocytosis: diagnosis, natural history, management, and outcome. Cancer. 1999; 85(10): 2278-90. PMid: 10326709. http://dx.doi.org/10.1002/(SICI) 1097-0142(19990515 ) $85: 10<2278:$ :AID-CNCR25>3.0.CO; $2-\mathrm{U}$

[8] Trojan A, Meier R, Licht A, et al. Eosinophilic pneumonia after administration of fludarabine for the treatment of non-Hodgkin's lymphoma. Annals of hematology. 2002; 81(9): 535-7. PMid: 12373357 http://dx.doi.org/10.1007/s00277-002-0497-9

[9] Kane GC, McMichael AJ, Patrick H, et al. Pulmonary toxicity and acute respiratory failure associated with fludarabine monophosphate. Respiratory medicine. 1992; 86(3): 261-3. PMid: 1377831. http://dx.doi.org/10.1016/S0954-6111(06)80066-1

[10] Samoszuk M. IgE in Reed-Sternberg cells of Hodgkin's disease with eosinophilia. Blood. 1992; 79(6): 1518-22. PMid: 1532136. http://dx.doi.org/10.1093/heapol/czh031

[11] Vaughan HB, Linch DC, Macintyre EA, et al. Selective peripheral blood eosinophilia associated with survival advantage in Hodgkin's disease (BNLI Report No 31). British National Lymphoma Investigation. Journal of clinical pathology. 1987; 40(3): 247-50. PMid: 3558857. http://dx.doi.org/10.1136/jcp.40.3.247

[12] Benharroch D, Guterman G, Levy I, et al. High content of Langerhans cells in malignant lymphoma-incidence and significance. Virchows Archiv: an international journal of pathology. 2010; 457(1): 63-7. PMid: 20473767. http://dx.doi.org/10.1007/s00428-010 -0931-7

[13] Greaves WO, Bueso-Ramos C, Fayad L. Classical Hodgkin's lymphoma associated with Langerhans cell histiocytosis: multiagent chemotherapy resulted in histologic resolution of both the classical Hodgkin's lymphoma and Langerhans cell proliferation components. Journal of clinical oncology: official journal of the American Society of Clinical Oncology. 2011; 29(4): e76-8. PMid: 21041711. http://dx.doi.org/10.1200/JC0.2010.31.2413

[14] Kjeldsberg CR, Kim H. Eosinophilic granuloma as an incidental finding in malignant lymphoma. Archives of pathology \& laboratory medicine. 1980; 104(3): 137-40. PMid: 6892595.

[15] L'Hoste RJ Jr, Arrowsmith WR, Leonard GL, et al. Eosinophilic granuloma occurring in a patient with Hodgkin disease. Human pathology. 1982; 13(6): 592-5. PMid: 7076242. http://dx.doi.org/10.10 $16 / \mathrm{S} 0046-8177(82) 80278-5$
[16] Hisada M, Biggar RJ, Greene MH, et al. Solid tumors after chronic lymphocytic leukemia. Blood. 2001; 98(6): 1979-81. PMid: 11535538. PMid: 11535538 . http://dx.doi.org/10.1182/blo od.v98.6.1979

[17] Maddocks-Christianson K, Slager SL, Zent CS, et al. Risk factors for development of a second lymphoid malignancy in patients with chronic lymphocytic leukaemia. British journal of haematology. 2007; 139(3): 398-404. http://dx.doi.org/10.1111/j.1 365-2141.2007.06801.x

[18] Royle JA, Baade PD, Joske D, et al. Second cancer incidence and cancer mortality among chronic lymphocytic leukaemia patients: a population-based study. British journal of cancer. 2011; 105(7): 107681. PMid: 21847118. http://dx.doi.org/10.1038/bjc. 2011. 313

[19] Travis LB, Curtis RE, Hankey BF, et al. Second cancers in patients with chronic lymphocytic leukemia. Journal of the National Cancer Institute. 1992; 84(18): 1422-7. PMid: 1512794. http: //dx.doi.org/10.1093/jnci/84.18.1422

[20] Bockorny B, Codreanu I, Dasanu CA. Hodgkin lymphoma as Richter transformation in chronic lymphocytic leukaemia: a retrospective analysis of world literature. British journal of haematology. 2012; 156(1): 50-66. PMid: 22017478. http://dx.doi.org/10.1111 /j.1365-2141.2011.08907.x

[21] Tadmor T, Shvidel L, Goldschmidt N, et al. Hodgkin's variant of Richter transformation in chronic lymphocytic leukemia; a retrospective study from the Israeli CLL study group. Anticancer research. 2014; 34(2): 785-90. PMid: 24511013.

[22] Richter MN. Generalized Reticular Cell Sarcoma of Lymph Nodes Associated with Lymphatic Leukemia. The American journal of pathology. 1928; 4(4): 285-92. PMid: 19969796.

[23] Swerdlow SCE, Harris NL, et al. in: Vardiman JW, ed. WHO Classification of Tumours of the Haematopoietic and Lymphoid Tissues, 4th edition. Geneva, Switzerland: World Health Organization. 2008.

[24] Parikh SA, Rabe KG, Call TG, et al. Diffuse large B-cell lymphoma (Richter syndrome) in patients with chronic lymphocytic leukaemia (CLL): a cohort study of newly diagnosed patients. British journal of haematology. 2013; 162(6): 774-82. PMid: 23841899. http://dx.doi.org/10.1111/bjh.12458

[25] Tsimberidou AM, O'Brien S, Kantarjian HM, et al. Hodgkin transformation of chronic lymphocytic leukemia: the M. D. Anderson Cancer Center experience. Cancer. 2006; 107(6): 1294-302. PMid: 16902984. http://dx.doi.org/10.1002/cncr. 22121

[26] Ohno T, Smir BN, Weisenburger DD, et al. Origin of the Hodgkin/Reed-Sternberg cells in chronic lymphocytic leukemia with "Hodgkin's transformation". Blood. 1998; 91(5): 1757-61. PMid: 9473243.

[27] Shin SS, Ben-Ezra J, Burke JS, et al. Reed-Sternberg-like cells in low-grade lymphomas are transformed neoplastic cells of B-cell lineage. American journal of clinical pathology. 1993; 99(6): 658-62 PMid: 8322699.

[28] van den Berg A, Maggio E, Rust R, et al. Clonal relation in a case of CLL, ALCL, and Hodgkin composite lymphoma. Blood. 2002; 100(4): 1425-9. PMid: 12149227.

[29] Kanzler H, Kuppers R, Helmes S, et al. Hodgkin and Reed-Sternberglike cells in B-cell chronic lymphocytic leukemia represent the outgrowth of single germinal-center B-cell-derived clones: potential precursors of Hodgkin and Reed-Sternberg cells in Hodgkin's disease. Blood. 2000; 95(3): 1023-31. PMid: 10648418.

[30] Pescarmona E, Pignoloni P, Mauro FR, et al. Hodgkin/ReedSternberg cells and Hodgkin's disease in patients with B-cell chronic lymphocytic leukaemia: an immunohistological, molecular and clinical study of four cases suggesting a heterogeneous pathogenetic 
background. Virchows Archiv: an international journal of pathology. 2000; 437(2): 129-32. PMid: 10993272.

[31] de Leval L, Vivario M, De Prijck B, et al. Distinct clonal origin in two cases of Hodgkin's lymphoma variant of Richter's syndrome associated With EBV infection. The American journal of surgical pathology. 2004; 28(5): 679-86. PMid: 15105659. http: //dx.doi.org/10.1097/00000478-200405000-00018

[32] Kazmierczak M, Kroll-Balcerzak R, Balcerzak A, et al. Hodgkin lymphoma transformation of chronic lymphocytic leukemia: cases report and discussion. Medical oncology. 2014; 31(1): 800. PMid: 24338339. http://dx.doi.org/10.1007/s12032-013 $-0800-8$

[33] Fais F, Ghiotto F, Hashimoto S, et al. Chronic lymphocytic leukemia B cells express restricted sets of mutated and unmutated antigen receptors. The Journal of clinical investigation. 1998; 102(8): 1515-25. PMid: 9788964. http://dx.doi.org/10.1172/JCI3009

[34] Hamblin TJ, Davis Z, Gardiner A, et al. Unmutated Ig V(H) genes are associated with a more aggressive form of chronic lymphocytic leukemia. Blood. 1999; 94(6): 1848-54. PMid: 10477713.

[35] Tzankov A, Fong D. Hodgkin's disease variant of Richter's syndrome clonally related to chronic lymphocytic leukemia arises in ZAP-70 negative mutated CLL. Medical hypotheses. 2006; 66(3): 577-9. PMid: 16223567. http://dx.doi.org/10.1016/j.mehy . 2005 .09 .007

[36] Brauninger A, Schmitz R, Bechtel D, et al. Molecular biology of Hodgkin's and Reed/Sternberg cells in Hodgkin's lymphoma. International journal of cancer Journal international du cancer. 2006; 118(8): 1853-61. PMid: 16385563. http://dx.doi.org/10.10 $02 /$ ijc. 21716

[37] Glaser SL, Lin RJ, Stewart SL, et al. Epstein-Barr virus-associated Hodgkin's disease: epidemiologic characteristics in international data. International journal of cancer Journal international du cancer. 1997; 70(4): 375-82. PMid: 9033642.

[38] Weiss LM. Epstein-Barr virus and Hodgkin's disease. Current oncology reports. 2000; 2(2): 199-204. PMid: 11122844. http: //dx.doi.org/10.1007/s11912-000-0094-9

[39] Kuppers R, Duhrsen U, Hansmann ML. Pathogenesis, diagnosis, and treatment of composite lymphomas. The Lancet Oncology. 2014;
15(10): e435-46. PMid: 25186047. http://dx.doi.org/10.10 16/S1470-2045(14)70153-6

[40] Fong D, Kaiser A, Spizzo G, et al. Hodgkin's disease variant of Richter's syndrome in chronic lymphocytic leukaemia patients previously treated with fludarabine. British journal of haematology. 2005; 129(2): 199-205. PMid: 15813847. http://dx.doi.org/10.11 $11 / j .1365-2141.2005 .05426 . x$

[41] Rai KR, Jain P. Chronic lymphocytic leukemia (CLL) - Then and Now. American journal of hematology. 2015. PMid: 26690614 http://dx.doi.org/10.1002/ajh.24282

[42] Cramer P, Langerbeins P, Eichhorst B, et al. Advances in first-line treatment of chronic lymphocytic leukemia: current recommendations on management and first-line treatment by the German CLL Study Group (GCLLSG). European journal of haematology. 2016; 96(1): 9-18. PMid: 26332019. http://dx.doi.org/10.1111/e jh. 12678

[43] Goede V, Fischer K, Busch R, et al. Obinutuzumab plus chlorambucil in patients with CLL and coexisting conditions. The New England journal of medicine. 2014; 370(12): 1101-10. PMid: 24401022 http://dx.doi.org/10.1056/NEJMoa1313984

[44] Eichhorst B, Fink AM, Busch R, et al. Frontline Chemoimmunotherapy with Fludarabine (F), Cyclophosphamide (C), and Rituximab (R) (FCR) Shows Superior Efficacy in Comparison to Bendamustine (B) and Rituximab (BR) in Previously Untreated and Physically Fit Patients (pts) with Advanced Chronic Lymphocytic Leukemia (CLL): Final Analysis of an International, Randomized Study of the German CLL Study Group (GCLLSG) (CLL10 Study). ASH Annual Meeting Abstracts. 2014.

[45] Fischer K, Cramer P, Busch R, et al. Bendamustine in combination with rituximab for previously untreated patients with chronic lymphocytic leukemia: a multicenter phase II trial of the German Chronic Lymphocytic Leukemia Study Group. Journal of clinical oncology: official journal of the American Society of Clinical Oncology. 2012; 30(26): 3209-16. PMid: 22869884. http: $/ / \mathrm{dx}$.doi.org/10.1200/JC0.2011.39.2688

[46] Fayad L, Robertson LE, O'Brien S, et al. Hodgkin's disease variant of Richter's syndrome: experience at a single institution. Leukemia \& lymphoma. 1996; 23(3-4): 333-7. PMid: 9031114. http://dx.d oi.org/10.3109/10428199609054836 